\title{
Withholding selective decontamination of the digestive tract from critically ill patients must now surely be ethically questionable given the vast evidence base
}

\author{
Durk F Zandstra ${ }^{1 *}$, Andy J Petros ${ }^{2}$, Nia Taylor ${ }^{3}$, Luciano Silvestri ${ }^{4}$, Miguel A de la Cal ${ }^{5}$, Hendrick KF van Saene ${ }^{3}$
}

See related Journal club critique by Shibli et al., http://ccforum.com/content/14/3/314

Shibli and colleagues recently commented [1] on the Dutch randomised controlled trial in which selective digestive decontamination (SDD) and selective oropharyngeal decontamination (SOD) were associated with significantly lower odds of death as compared with standard care, with odds ratios of $0.83(P=0.02)$ and 0.86 $(P=0.045)$, respectively [2]. We disagree with the authors' conclusion that, because there were similar mortality reductions, SOD may be preferred as this avoids routinely exposing patients to intravenous antibiotics and involves less resistance.

Cephalosporin consumption was higher in the SDD group, but defined daily doses of penicillins, carbapenems, quinolones and other antibiotics increased by $31 \%, 37 \%, 25 \%$ and $15 \%$, respectively, in SOD compared with SDD in the Dutch randomised controlled trial [2].

In citing the monthly point prevalence survey [3] of the Dutch randomised controlled trial, Shibli and colleagues failed to mention that the average prevalence of aerobic Gram-negative bacilli resistant to ceftazidime, tobramycin and ciprofloxacin in the respiratory tract was significantly lower during SDD/SOD than in the pre-intervention and post-intervention periods, and that aerobic Gram-negative bacilli resistance to ciprofloxacin and tobramycin in rectal swabs was significantly reduced during SDD compared with standard care/SOD $[2,3]$.

Finally, two recent meta-analyses evaluated the effectiveness of SDD [4] and of SOD [5]: lower airway infections were significantly reduced by both SDD and SOD,

\footnotetext{
* Correspondence: d.f.zandstra@olvg.nl

${ }^{1}$ Department of Intensive Care, Onze Lieve Vrouwe Gasthuis, $1^{\text {st }}$ Oosterpark str 279, 1090 HM Amsterdam, The Netherlands

Full list of author information is available at the end of the article
}

but only SDD was associated with a significant survival benefit.

We believe that withholding SDD is now ethically questionable given the vast body of evidence on the technique reducing severe infections and mortality, requiring less antibiotic use, and providing less resistance.

\section{Abbreviations \\ SDD: selective digestive decontamination; SOD: selective oropharyngeal decontamination.}

\section{Author details}

'Department of Intensive Care, Onze Lieve Vrouwe Gasthuis, $1^{\text {st }}$ Oosterpark str 279, 1090 HM Amsterdam, The Netherlands. ${ }^{2}$ Paediatric Intensive Care Unit, Great Ormond Street Children's Hospital, London WC1N 3JH, UK. ${ }^{3}$ School of Clinical Sciences, University of Liverpool, Liverpool L69 3GA, UK. ${ }^{4}$ Department of Emergency, Unit of Anaesthesia and Intensive Care, Presidio Ospedaliero, 34170 Gorizia, Italy. ${ }^{5}$ Unidad de Cuidados Intensivos y Grandes Quemados, Hospital Universitario de Getafe, Getafe, Madrid, Spain.

\section{Competing interests}

The authors declare that they have no competing interests.

Published: 6 October 2010

\section{References}

1. Shibli AB, Milbrandt EB, Baldisseri M: Dirty mouth? Should you clean it out? Decontamination for the prevention of pneumonia and mortality in the ICU. Crit Care 2010, 14:314.

2. Smet AM, Kluytmans JA, Cooper BS, Mascini EM, Benus RF, van der Werf TS, van der Hoeven JG, Pickkers P, Bogaers-Hofman D, van der Meer NJ, Bernards AT, Kuijper EJ, Joore JC, Leverstein-van Hall MA, Bindels AJ, Jansz AR, Wesselink RM, de Jongh BM, Dennesen PJ, van Asselt GJ, te Velde $L F$, Frenay $\mathrm{IH}$, Kaasjager $\mathrm{K}$, Bosch $\mathrm{FH}$, van Iterson $\mathrm{M}$, Thijsen SF, Kluge GH, Pauw W, de Vries JW, Kaan JA, et al: Decontamination of the digestive tract and oropharynx in ICU patients. N Engl J Med 2009, 360:20-31

3. Oostdijk EAN, de Smet AMGA, Blok HEM, Thieme Groen ES, van Asselt GJ, Benus RFJ, Bernards SAT, Frenay IHME, Jansz AR, de Jongh BM, Kaan JA, Leverstein-van Hall MA, Mascini EM, Pauw W, Sturm PDJ, Thijsen SFT, 
Kluytmans JAJW, Bonten MJM: Ecological effects of selective decontamination on resistant Gram-negative bacterial colonisation. Am J Respir Crit Care Med 2010, 181:452-457.

4. Liberati A, D'Amico R, Pifferi S, Torri V, Brazzi L, Parmelli E: Antibiotic prophylaxis to reduce respiratory tract infections and mortality in adults receiving intensive care. Cochrane Database Systematic Review 2009, 4: CD000022.

5. Silvestri L, van Saene HKF, Zandstra DF, Viviani M, Gregori D: SDD, SOD, or oropharyngeal chlorhexidine to prevent pneumonia and to reduce mortality in ventilated patients: which manoeuvre is evidence based? Intensive Care Med 2010, 36:1436-1437.

doi:10.1186/cc9255

Cite this article as: Zandstra et al.: Withholding selective

decontamination of the digestive tract from critically ill patients must

now surely be ethically questionable given the vast evidence base.

Critical Care 2010 14:443.

\section{Submit your next manuscript to BioMed Central} and take full advantage of:

- Convenient online submission

- Thorough peer review

- No space constraints or color figure charges

- Immediate publication on acceptance

- Inclusion in PubMed, CAS, Scopus and Google Scholar

- Research which is freely available for redistribution

Submit your manuscript at www.biomedcentral.com/submit
Ciomed Central 